\title{
Analisis $\quad$ Faktor-Faktor yang Mempengaruhi Kesiapan Kerja Pramusaji untuk Meningkatkan Kualitas Pelayanan pada El Patio Restaurant di Melia Bali
}

\author{
Ni Made Suastini* \\ Sekolah Tinggi Pariwisata Nusa Dua Bali
}

\begin{abstract}
Abstrak
Kesiapan kerja merupakan persyaratan pengetahuan, sikap dan keterampilan yang harus dimiliki karyawan sebelum memulai pekerjaan untuk dapat memberikan pelayanan yang berkualitas kepada tamu. Penelitian ini dilakukan di El Patio Restaurant Melia Bali, yang bertujuan untuk mengetahui faktor-faktor apa saja yang menyebabkan menurunnya kualitas pelayanan di El Patio Restaurant. Penelitian ini menggunakan analisis mix method yaitu dengan mengkuantitatifkan data kualitatif dan mengkualitatifkan data kuantitatif dengan menyebarkan 15 kuesioner kepada pramusaji untuk menilai dirinya sendiri dan 15 kuesioner kepada manajer untuk menilai setiap pramusaji. Hasil penelitian ini menunjukkan bahwa terdapat beberapa aspek pada pengetahuan, sikap dan keterampilan pramusaji yang masih kurang. Hal tersebut menjadi faktor-faktor yang mempengaruhi menurunnya kualitas pelayanan

\begin{tabular}{lr} 
Keywords: & \\
\hline & \\
Pramusaji, & Kesiapan \\
Kerja, & Kualitas \\
Pelayanan &
\end{tabular}

di El Patio Restaurant khususnya pada kesiapan kerja, diantaranya adalah: (1) Berbicara dalam Bahasa Inggris, (2) Kemampuan dalam memberikan penjelasan ingredients menu di El Patio Restaurant, (3) Kemampuan dalam memberikan penjelasan tentang method of cooking dari setiap menu, (4) Etika terhadap rekan kerja, atasan dan tamu, (5) Kemampuan mengendalikan emosi, (6) Kemauan menerima masukan, arahan dan kritikan, (7) Terampil menjaga dan memelihara kebersihan peralatan.
\end{abstract}

\section{PENDAHULUAN}

Departemen personalia sebagai departemen yang mengelola sumber daya manusia pada sebuah hotel, berfungsi dalam pengadaan karyawan, pengembangan karyawan, dan pemeliharaan karyawan. Dalam pengadaan karyawan departemen personalia umumnya melakukan beberapa proses, yaitu proses rekrutmen, proses seleksi, dan proses penempatan karyawan. Proses dalam pengadaan karyawan dimaksudkan agar calon karyawan yang diterima bekerja di hotel memiliki kesiapan kerja yang baik sehingga dapat melaksanakan tugas dan tanggung jawab sesuai Standar Operational Procedure yang telah ditetapkan oleh pihak manajemen hotel. Dengan memiliki kesiapan kerja yang sesuai dengan standar, diharapkan para karyawan memberikan pelayanan yang berkualitas kepada tamu.

Hotel Melia Bali Indonesia memiliki Quality Control Department yang bertanggung jawab untuk memonitor dan menilai kualitas pelayanan bagian-bagian yang ada di Hotel Melia Bali setiap bulannya. Hasil quality control setiap bulan tersebut kemudian diakumulasi setiap tahunnya. Berikut pada tabel 1 akan ditampilkan rata-rata tingkat kualitas pelayanan setiap departemen yang berhubungan langsung dalam melayani tamu di Hotel Melia Bali Indonesia pada tahun 2016 dan 2017 yang diolah dari Quality Result.

\footnotetext{
* Corresponding author. 
Tabel 1 Rata-Rata Tingkat Kualitas Pelayanan di Melia Bali Tahun 2016 - 2017

\begin{tabular}{lllll}
\hline No. & $\frac{\text { Tahun }}{2016}$ & $\frac{2017}{80,5}$ & $\frac{\text { Perbandingan }}{80,7}$ \\
$\frac{1}{2}$ & $\frac{\text { Room }}{3}$ & $\frac{8,2}{87,1}$ & $\frac{87}{83,7}$ & $\frac{-0,1}{83,2}$ \\
$\frac{\text { Front Desk }}{4}$ & $\frac{\text { Activities }}{\text { Food \& Beverage }}$ & $\frac{-0,5}{86,5}$ & $\frac{-1,8}{84,7}$ \\
\hline
\end{tabular}

Sumber: Quality Control Department

Food \& Beverage Service Department mengalami penurunan yang paling besar dibandingkan dengan departemen lainnya, yaitu dari angka 86,5 \% di tahun 2016 ke angka 84,7 \% di tahun 2017, penurunan kualitas pelayanan sebesar 1,8 \%, kemudian pada departemen Activities nilai kualitas pelayanan mengalami penurunan sebesar 0,5\% dari 83,7 \% menjadi 83,2 \%. Pada departemen Front Desk mengalami penurunan sebesar 0,1 \%, yaitu dari nilai kualitas sebesar 87,1 \% di tahun 2016 menurun ke $87 \%$ di tahun 2017 dan yang terakhir pada departemen Room mengalami peningkatan sebesar 0,2 \%, yaitu dari 80,5 \% bertambah menjadi 80,7 \%. Dari data pada tabel 1, dapat disimpulkan bahwa kualitas pelayanan pada departemen Food \& Beverage Service mengalami penurunan paling besar, sehingga perlu dilakukan analisa lebih lanjut mengenai masalah yang terjadi.

Informasi yang diperoleh bahwa penurunan di departemen Food \& Beverage Service terdapat tiga restoran yang mengalami penurunan dan dua restoran mengalami peningkatan kualitas pelayanan. Adapun yang mengalami penurunan kualitas pelayanan adalah Sateria Restaurant sebesar 2,4 \% yaitu dari 87,1 \% menjadi 84,7 \%, berikutnya Lotus Restaurant mengalami penurunan sebesar 5 \% dari 87,9 \% menjadi 82,9 \% dan yang terakhir El Patio Restaurant mengalami penurunan sebesar 8,7 \%. Sedangkan restoran yang mengalami peningkatan nilai kualitas pelayanan adalah Sorrento dan Sakura Restaurant. Sorrento Restaurant mengalami peningkatan sebesar $1 \%$, dari 90,7 \% menjadi 91,7 \%, sedangkan Sakura Restaurant mengalami peningkatan nilai kualitas pelayanan yang cukup tinggi sebesar 12,2\%, dengan nilai kualitas pelayanan di tahun 2016 sebesar 82,2 \% dan nilai kualitas pelayanan di tahun 2017 sebesar 94,4 \%. Restoran yang mengalami penurunan kualitas pelayanan paling besar adalah El Patio Restaurant, yaitu sebesar 8,7 \%. Hasil tersebut tidak sesuai dengan standar yang telah ditetapkan oleh pihak manajemen yaitu meningkat sebesar 0,2 \% setiap tahun. Diduga penyebab terjadinya penurunan kualitas pelayanan adalah kesiapan karyawan dalam bekerja.

Nawawi (2008:108) mengemukakan bahwa kesiapan kerja merupakan persyaratan pengetahuan, keterampilan atau keahlian, kemampuan mental, fisik dan sifat-sifat kepribadian tertentu yang dipersyaratkan bagi seorang karyawan untuk dapat melaksanakan pekerjaan atau jabatan tertentu secara efektif dan efisien. Dari definisi tersebut dapat dikatakan bahwa kesiapan kerja merupakan kemampuan yang harus dimiliki karyawan atau calon karyawan yang mencakup pengetahuan, keterampilan dan sikap untuk dapat melaksanakan pekerjaan sesuai dengan beban dan tanggung jawab dari suatu jabatan tertentu secara efektif dan efisien.

Salah satu cara untuk meningkatkan kesiapan kerja karyawan, yaitu melalui pelatihan (training). Training biasanya dilakukan untuk meningkatkan kemampuan pada pengetahuan, sikap dan keterampilan karyawan. Dalam pelaksanaannya ada beberapa jenis metode yang umum digunakan oleh hotel. Hal ini sangat bergantung pada tipe pelatihan yang akan diberikan dan karakteristik peserta. Haraindja (2009: 184) mengatakan "Metode pelatihan yang biasanya digunakan bisa dalam bentuk on the job training dan off the job training. On the job training adalah pelatihan dan pengembangan yang dilakukan pada waktu jam kerja berlangsung baik secara formal maupun informal. On the job training terdiri dari (a) Job instruction training, (b) Coaching. (c) Job rotation, (d) Apprenticeship/intership. Off the job training adalah pelatihan dan pengembangan yang dilakukan secara khusus diluar pekerjaan. Off the job training terdiri dari (a) Lecture, (b) Video Presentasi, (c) Vestibule Training/simulation, (d) Role Playing , (e) Self - Study, (f) Program Learning, (g) Laboratory Training, (h) Action Learning.

El Patio Restaurant merupakan salah satu restoran terluas di Melia Bali Indonesia. Restoran dengan kategori coffee shop ini merupakan restoran dengan kapasitas kursi sebanyak 350 orang dan dibuka 
selama 24 jam. Hal tersebut menyebabkan rata-rata tamu yang harus dilayani oleh pramusaji cukup padat. El Patio Restaurant sangat sibuk dengan kegiatan breakfast, lunch dan dinner. Jumlah pesanan yang harus dilayani oleh pramusaji di El Patio Restaurant pada bulan Januari hingga Desember 2017 sebanyak 312.583 pax, dengan jumlah pesanan untuk breakfast sebanyak 283.127 pax, lunch sebanyak 10.375 pax dan dinner sebanyak 19.081 pax. Dengan jumlah pesanan yang cukup banyak tersebut, pramusaji di $E l$ Patio Restaurant diharapkan harus memiliki kesiapan kerja yang baik dalam melayani tamu. Berdasarkan permasalahan yang telah dipaparkan maka penelitian ini akan meneliti mengenai faktor-faktor yang mempengaruhi kesiapan kerja pramusaji yang menyangkut pengetahuan, sikap dan keterampilan.

\section{METODE PENELITIAN}

Metode penelitian ini menggunakan analisis secara deskriptif dengan menggunakan statistik deskriptif yaitu mempelajari cara pengumpulan data dan penyajian data sehingga mudah dipahami, metode ini berhungungan dengan hal menguraikan atau memberikan keterangan-keterangan mengenai suatu data atau keadaan atau fenomena (Hasan, 2001:7).

Teori yang akan digunakan sebagai acuan adalah teori Taksonomi Bloom (dalam Uno, 2012: 15) yang mengemukakan kesiapan kerja seseorang berhubungan dengan aspek kepribadian yang mempengaruhi kemampuan (Observable Behavior). Aspek tersebut dapat dibagi menjadi tiga jenis yaitu: (1) Cognitiv Domain (Pengetahuan), (2) Affective Domain (Sikap) dan Psychomotor Domain (Keterampilan).

Dengan menyebarkan 15 kuesioner terhadap karyawan yang bersangkutan dan 15 kuesioner terhadap manager untuk mendapatkan hasil yang akurat. Hasil dari penelitian ini akan membandingkan kuesioner berdasarkan diri sendiri dan manager.

\section{ANALISIS DAN PEMBAHASAN}

Untuk mendapatkan data tentang latar belakang pendidikan, usia, jenis kelamin dan masa kerja semua pramusaji di El Patio Restaurant, telah dilakukan studi dokumentasi dengan mempelajari dokumen yang didapat dari hotel. Latar belakang pendidikan pramusaji di El Patio Restaurant sudah memenuhi standar persyaratan kerja yang ditetapkan oleh manajemen hotel dengan rata-rata lulusan diploma, hanya saja terdapat enam orang ( $40 \%$ ) pramusaji dengan latar pendidikan SMA, akan tetapi telah memiliki ratarata masa kerja diatas 15 tahun. Usia pramusaji di El Patio Restaurant yang rata-rata diatas 40 tahun, dapat berdampak pada performa kerja yang mengalami penurunan. Sebagian besar pramusai di El Patio Restaurant adalah perempuan $(53,33 \%)$, dimana ketahanan fisik perempuan cenderung kurang dibandingkan dengan pria pada saat beban kerja yang tinggi. Dan pengalaman masa kerja pramusaji di $E l$ Patio Restaurant yang berkisar antara 2-30 tahun.

Selain hal tersebut untuk meningkatkan pengetahuan, sikap dan keterampilan pramusaji di El Patio Restaurant, pihak manajemen telah melakukan berbagai kebijakan, diantaranya dengan mengadakan orientasi dan program pelatihan. Dari hal itu seharusnya pramusaji di El Patio Restaurant memiliki kesiapan kerja yang baik, namun pada kenyataannya pramusaji di El Patio Restaurant masih memiliki kesiapan kerja yang rendah. Hal ini dapat dilihat dari pramusaji di El Patio Restaurant yang menjalankan tugas tidak sesuai dengan Standard Operating Procedure yang ditetapkan pihak manajemen sehingga menyebabkan timbulnya banyak keluhan dari tamu yang ditujukan untuk bagian El Patio Restaurant.

Untuk mengetahui tingkat kesiapan kerja pramusaji pada El Patio Restaurant di Hotel Melia Bali, telah disebarkan 15 kuesioner kepada 15 orang pramusaji di El Patio Restaurant untuk menilai kesiapan kerja dirinya sendiri dan 15 kuesioner juga diberikan kepada El Patio Restaurant Manager sebagai atasan langsung dari pramusaji di El Patio Restaurant untuk menilai bawahannya. Dari 30 kuesioner yang telah disebarkan seluruhnya (100 \%) dikembalikan dan diisi dengan lengkap. Dari data hasil kuesioner tersebut dilakukan penilaian menggunakan Skala Likert dan dianalisis dengan menggunakan teori Taksonomi Bloom. Dalam setiap kuesioner yang disebarkan, masing-masing terdapat 46 butir pertanyaan tentang kesiapan kerja pramusaji di El Patio Restaurant, setiap pertanyaan dalam kuesioner tersebut terdapat empat pilihan jawaban, yaitu sangat baik, baik, kurang dan sangat kurang. Terpilihnya baik dan sangat baik $(2,50-4,00)$ menunjukkan kecenderungan positif, dengan kata lain kesiapan kerja pramusaji di El Patio Restaurant dinilai sudah baik. Sedangkan terpilihnya kurang dan sangat kurang $(1,00-2,49)$ menunjukkan kecenderungan negatif, dengan kata lain kesiapan kerja pramusaji di El Patio Restaurant dinilai kurang. 
Hasil kuesioner menurut penilaian diri sendiri terkait kesiapan kerja pramusaji pada El Patio Restaurant mengalami kecenderungan positif. Penjelasan pada masing-masing aspek dapat dijabarkan sebagai berikut:

a. Aspek Pengetahuan

Aspek pengetahuan menunjukan kecenderungan positif dengan rata-rata nilai 3,04. Penjabaran poin-poin pada aspek pengetahuan yaitu: 1) Pengetahuan tentang Bahasa Inggris menunjukan kecenderungan positif dengan rata-rata nilai 2,77. Nilai tertinggi adalah 3,13 dan nilai terendah adalah 2,47.2) Pengetahuan tentang menu menunjukan kecenderungan positif dengan rata-rata nilai 2,91. Nilai tertinggi adalah 3,13 dan nilai terendah adalah 2,73. 3) Pengetahuan tentang menggunakan telephone menunjukan kecenderungan positif dengan rata-rata nilai 3,53.4) Pengetahuan tentang prosedur service menunjukan nilai positif yaitu 3,13 yang berarti dinilai baik. 5) Pengetahuan tentang peralatan menunjukan kecenderungan positif yaitu dengat rata-rata 3,29.

b. Aspek Sikap

Pada aspek sikap menunjukan kecenderungan positif dengan rata-rata nilai 3,08. Penjabaran poinpoin pada aspek sikap yaitu: 1) Sikap tentang disiplin waktu kerja menunjukan kecenderungan positif dengan rata-rata 2,92. Dengan nilai tertinggi 3,07 dan nilai terendah 2,53. 2) Sikap tentang disiplin penampilan menunjukan kecenderungan positif dengan rata-rata 3,19. Dengan nilai tertinggi 3,40 dan nilai terendah 3,07. 3)Sikap dalam berperilaku menunjukan kecenderungan positif dengan rata-rata 3,07. Dengan nilai tertinggi 3,40 dan nilai terendah 2,53.

c. Aspek Keterampilan

Aspek keterampilan menunjukan kecenderungan positif dengan rata-rata nilai 3. Penjabaran poinpoin pada aspek keterampilan yaitu: 1) Keterampilan dalam Bahasa Inggris menunjukan nilai positif yaitu 3,13 dinilai baik pada poin terampil dalam memahami maksud tamu yang berbicara dengan Bahasa Inggris. 2) Keterampilan dalam prosedur service menunjukan kecenderungan positif dengan rata-rata 3,08. Dengan nilai tertinggi 3,40 dan nilai terendah 2,73.3) Keterampilan dalam menggunakan peralatan menunjukan kecenderungan positif dengan rata-rata 2,84. Dengan nilai tertinggi 2,87 dan nilai terendah 2,80. 4) Keterampilan dalam memproses tagihan menunjukan nilai positif dengan rata-rata 2,90.5) Keterampilan dalam table set-up mendapatkan nilai positif yaitu 3,13.6) Keterampilan dalam menangani keluhan mendapatkan rata-rata nilai positif yaitu 3 .

Sedangkan hasil kuesioner menurut penilaian manajer terkait kesiapan kerja pramusaji pada $E l$ Patio Restaurant mengalami kecenderungan positif. Penjelasan pada masing-masing aspek dapat dijabarkan sebagai berikut:

a. Aspek Pengetahuan

Aspek pengetahuan menunjukan kecenderungan positif dengan rata-rata nilai 2,98. Penjabaran poin-poin pada aspek pengetahuan yaitu: 1) Pengetahuan berbahasa Inggris menunjukan nilai positif dengan rata-rata nilai 2,60. Dengan nilai tertinggi 2,87 dan nilai terendah 2,13,2) Pengetahuan menu menunjukan nilai positif dengan rata-rata nilai 2,87. Dengan nilai tertinggi 3,87 dan nilai terendah $2,47,3$ ) Pengetahuan menggunakan telepon menunjukan nilai positif dengan rata-rata 3,50,4) Pengetahuan prosedur servis mendapatkan nilai 3,73 yang menunjukan pengetahuan pramusaji dalam memahami prosedur pelayanan di El Patio Restaurant dinilai sangat baik, 5) Pengetahuan peralatan menunjukan kecenderungan positif dengan rata-rata nilai 3,07. Dengan nilai tertinggi 3,20 dan nilai terendah 2,87.

b. Aspek Sikap

Aspek sikap menunjukan kecenderungan positif dengan rata-rata nilai 2,95. Penjabaran poinpoin pada aspek sikap yaitu: 1) Sikap tentang disiplin waktu kerja menunjukan kecenderungan positif dengan rata-rata 3,03. Dengan nilai tertinggi 3,20 dan nilai terendah 2,73, 2) Sikap tentang disiplin dalam berpenampilan menunjukan kecenderungan positif dengan rata-rata nilai 3,11. Dengan nilai tertinggi 3,20 dan nilai terendah 2,93,3) Sikap pramusaji dalam berperilaku menunjukan kecenderungan positif dengan rata-rata nilai 2,72. Dengan nilai tertinggi 3,20 dan nilai terendah 2,27.

c. Aspek Keterampilan

Aspek keterampilan menunjukan kecenderungan positif dengan rata-rata nilai 2,89. Penjabaran poin-poin pada aspek keterampilan yaitu: 1) Keterampilan dalam berbahasa Inggris mendapatkan nilai 3 yang menunjukan keterampilan pramusaji dalam memahami maksud tamu yang berbicara dengan Bahasa Inggris dinilai baik, 2) Keterampilan dalam prosedur servis menunjukan kecenderungan positif dengan rata- rata nilai 2,94. Dengan nilai tertinggi 3,20 dan nilai terendah 2,60, 3) Keterampilan dalam menggunakan peralatan servis menunjukan kecenderungan negatif dengan nilai rata-rata 2,49, 4)Keterampilan dalam memproses tagihan mendapatkan nilai rata-rata 3,43, 5)Keterampilan dalam table set-up mendapatkan nilai 3,27 yang menunjukan kemampuan pramusaji dalam table set-up dinilai sangat baik, 6)Keterampilan dalam menangani keluhan mendapatkan rata-rata nilai 2,53. 
Hasil kuesioner dari penilaian diri sendiri dan penilaian dari manajer diperbandingkan untuk melihat gap penilaiannya. Tabel 2 di bawah ini menyajikan informasi perbandingan penilaian kesiapna kerja karyawan.

Tabel 2 Penilaian Kesiapan Kerja berdasarkan Diri Sendiri dan Manager

\begin{tabular}{|c|c|c|c|}
\hline \multirow[t]{2}{*}{ No } & \multirow[t]{2}{*}{ Faktor } & \multirow{2}{*}{$\begin{array}{c}\text { Penilaian } \\
\text { Diri Sendiri } \\
\end{array}$} & \multirow{2}{*}{$\begin{array}{l}\text { Penilaian } \\
\text { Manager }\end{array}$} \\
\hline & & & \\
\hline \multirow[t]{7}{*}{1} & Pengetahuan & & \\
\hline & a. Pengetahuan Bahasa Inggris & 2,77 & 2,60 \\
\hline & b. Pengetahuan Menu & 2,91 & 2,87 \\
\hline & c. Pengetahuan Menggunakan Telephone & 3,53 & 3,50 \\
\hline & d. Pengetahuan Prosedure Service & 3,13 & 3,73 \\
\hline & e. Pengetahuan Peralatan & 3,29 & 3,07 \\
\hline & Rata-rata & 3,13 & 3,15 \\
\hline \multirow[t]{5}{*}{2} & Sikap & & \\
\hline & a. Disiplin Waktu Kerja & 2,92 & 3,03 \\
\hline & b. Disiplin Penampilan & 3,19 & 3,11 \\
\hline & c. Perilaku & 3,07 & 2,72 \\
\hline & Rata-rata & 3,06 & 2,95 \\
\hline \multirow[t]{8}{*}{3} & Keterampilan & & \\
\hline & a. Keterampilan Dalam Berbahasa Inggris & 3,13 & 3,00 \\
\hline & b. Keterampilan Dalam Prosedure Service & 3,08 & 2,94 \\
\hline & c. Keterampilan Dalam Menggunakan Peralatan & 2,84 & 2,49 \\
\hline & d. Keterampilan Dalam Memproses Tagihan & 2,90 & 3,43 \\
\hline & e. Keterampilan Dalam table set-up & 3,13 & 3,27 \\
\hline & f. Keterampilan Dalam Menangani Keluhan & 3,00 & 2,53 \\
\hline & Rata-rata & 3,01 & 2,94 \\
\hline
\end{tabular}

Sumber: Hasil Olah Kuesioner

Secara keseluruhan kesiapan kerja pramusaji pada El Patio Restaurant berdasarkan penilaian diri sendiri dan manager pada tabel 2 mengalami kecenderungan positif, penjelasan pada masing-masing aspek dapat dijabarkan sebagai berikut:

1. Pengetahuan

Pada aspek pengetahuan dapat dilihat rata-rata nilai kesiapan kerja pramusaji mendapatkan kecenderungan positif. Hasil analisis berdasarkan penilaian diri sendiri mendapatkan nilai 3,13 yang menunjukan bahwa pengetahuan pramusaji dinilai baik dan penilaian kesiapan kerja pramusaji berdasarkan penilaian manager mendapatkan nilai 3,15 yang menunjukan bahwa kesiapan kerja pramusaji pada pengetahuan dinilai baik. Sehingga pramusaji dan manager memiliki pendapat yang sama mengenai pengetahuan. Pengetahuan pramusaji telah dinilai baik dan harus tetap dipertahankan.

2. Sikap

Pada aspek sikap dapat dilihat rata-rata nilai kesiapan kerja pramusaji mendapatkan kecenderungan positif. Hasil analisis kuesioner kesiapan kerja pramusaji berdasarkan diri sendiri mendapatkan nilai 3,06 yang menunjukan bahwa menurut pramusaji kesiapan kerjanya dalam segi sikap sudah dinilai baik dan hasil analisis kuesioner berdasarkan manager mendapatkan nilai 2,95 yang menunjukan bahwa menurut manager kesiapan kerja pramusaji sudah dapat dikatakan baik. Berdasarkan kedua hasil analisis dapat disimpulkan bahwa menurut pramusaji dan manager kesiapan kerja dari segi sikap sudah baik dan perlu dipertahankan.

3. Keterampilan 
Pada aspek keterampilan dapat dilihat rata-rata nilai kesiapan kerja pramusaji mendapatkan kecenderungan positif. Hasil analisis kuesioner kesiapan kerja pramusaji berdasarkan penilaian diri sendiri mendapatkan nilai 3,01 yang menunjukan kesiapan kerja pramusaji menurut penilaian diri sendiri sudah dinilai baik dan hasil analisis kuesioner kesiapan kerja pramusaji menurut manager mendapatkan nilai 2,94 yang menunjukan bahwa menurut manager nilai kesiapan kerja pramusaji sudah baik, sehingga harus terus ditingkatkan.

Berdasarkan ketiga perbandingan hasil analisis menurut penilaian diri sendiri dan menurut penilaian manager dapat dilihat bahwa pramusaji rata-rata memberikan nilai terhadap dirinya sendiri dengan angka yang lebih tinggi, sedangkan manager yang menilainya memberikan angka berdasarkan kenyataan yang terlihat pada kegiatan operasional sehari-hari. Oleh karena itu maka disebarkan pertanyaan kuesioner melalui kedua aspek agar mendapatkan hasil analisis yang akurat.

\section{KESIMPULAN}

Berdasarkan hasil analisis data berikut ini akan dideskripsikan kesimpulan dan saran berkaitan dengan kesiapan kerja pramusaji di El Patio Restaurant pada Hotel Melia Bali. Kesiapan kerja pramusaji di El Patio Restaurant dari aspek pengetahuan, sikap dan keterampilan secara umum menunjukan kecenderungan positif, dengan kata lain dinilai cukup baik. Tetapi pada beberapa poin penting pada aspek pengetahuan, sikap dan keterampilan pramusaji di El Patio Restaurant masih mendapat nilai kurang yang dapat menjadi faktor-faktor penyebab masih rendahnya kesiapan kerja pramusaji dalam memberikan pelayanan yang berkualitas kepada tamu, sehingga tingkat kualitas pelayanan menurun dan tamu merasa kurang puas dengan pelayanan yang diberikan. Adapun faktor-faktor yang mendapatkan penilaian kurang terkait kesiapan kerja pramusaji di El Patio Restaurant menurut Manager adalah :1) Berbicara dalam Bahasa Inggris dengan grammar yang benar, 2) Kemampuan menjelaskan Ingredients menu di El Patio Restaurant dengan baik, 3) Kemampuan menjelaskan method of cooking dari setiap menu dengan baik, 4) Etika terhadap rekan kerja, atasan dan tamu, 5) Kemampuan mengendalikan emosi, 6) Kemauan menerima masukan, arahan dan kritikan, 7) Terampil menjaga dan memelihara kebersihan peralatan

Dan faktor-faktor yang perlu ditingkatkan setelah diakumulasi berdasarkan penilaian manager dengan penilaian diri sendiri adalah 1) Berbicara dalam Bahasa Inggris dengan grammar yang benar, 2) Kemampuan mengendalikan emosi

\section{DAFTAR PUSTAKA}

Agus Mertayasa, I Gede. 2012. Food \& Beverage Service Operational. Andi: Yogyakarta.

Dessler, Gary. 2007. Manajemen Sumber Daya Manusia. Edisi Kesepuluh. Jakarta:Indeks

Fathoni, Abdurahmat. 2006. Metodologi Penelitian dan Teknik Penyusunan Skripsi. Jakarta: PT. Rineka Cipta.

Hamzah, B. Uno. 2012. Orientasi Baru Dalam Psikologi Pembelajaran. Jakarta: Bumi Aksara.

Hariandja, Marihot Tua Effendi. 2009. Manajemen Sumber Daya Manusia. Jakarta:Grasindo.

Hasibuan, H. Melayu S.P. 2007. Manajemen Sumber Daya Manusia, Edisi revisi. Jakarta: Bumi Aksara.

Martoyo, Sosilo. 2001. Manajemen Sumber Daya Manusia, Edisi Kelima. Yogyakarta: BPFE.

Marsum, WA. 2005. Restoran dan Segala Permasalahannya. Andi: Yogyakarta.

Moleong, Lexy. 2001. Metodologi Penelitian Kualitatif. Bandung: PT. Remaja Rosdakarya.

Nawawi, Hadari H. 2008. Manajemen Sumber Daya Manusia. Yogyakarta: Gadjah Mada University Press.

Pendit, Soekresno. 2005. Petunjuk Praktek Pramusaji. Jakarta: Gramedia.

Rivai, Vethzal. 2009. Manajemen Sumber Daya Manusia untuk Perusahaan, dari Teori ke Praktek. Jakarta: Rajawali Pers 
Sulastiyono, Agus. 2008. Manajemen Penyelenggaraan Hotel. Bandung: Alfabeta.

Suryabrata, Sumadi. 2003. Metodologi Penelitian. Jakarta: PT. Raja Grafindo Persada.

Tjiptono, Fandy. 2003. Total Quality Management, Edisi Kelima. Yogyakarta: Andi

Wiwoho, Ardjuno. 2008. Pengetahuan Tata Hidang. Jakarta: Erlangga. 